\title{
Evidence of Reproductive Disturbance in Astyanax Lacustris (Teleostei: Characiformes) From the Doce River After the Collapse of the Fundão Dam in Mariana, Brazil
}

Julia Merçon ( $\square$ julia.merconf@gmail.com )

Vila Velha University: Universidade Vila Velha https://orcid.org/0000-0001-5089-6333

\section{Dandara Silva Cabral}

Vila Velha University: Universidade Vila Velha

\section{Bárbara Chisté Teixeira}

Vila Velha University: Universidade Vila Velha

\section{Tatiana Miura Pereira}

Vila Velha University: Universidade Vila Velha

\section{Alliny Bona}

Vila Velha University: Universidade Vila Velha

\section{Catharina Valadares}

Vila Velha University: Universidade Vila Velha

Silvia Nascimento

Vila Velha University: Universidade Vila Velha

\section{Levy Carvalho Gomes}

Vila Velha University: Universidade Vila Velha

\section{Research Article}

Keywords: Lambari, contamination, metals, bioconcentration, histological damage, spawning.

Posted Date: February 15th, 2021

DOI: https://doi.org/10.21203/rs.3.rs-171535/v1

License: (c) (i) This work is licensed under a Creative Commons Attribution 4.0 International License. Read Full License

Version of Record: A version of this preprint was published at Environmental Science and Pollution Research on July 7th, 2021. See the published version at https://doi.org/10.1007/s11356-021-15238-x. 


\section{Abstract}

On November $5^{\text {th }}, 2015$, the Fundão Dam collapsed dumping more than 50 million $/ \mathrm{m}^{3}$ of iron ore tailings, enriched with metals, into the Doce River channel. The objective of this study was to evaluate the reproductive biology and histological damage in Astyanax lacustris exposed to the metals from the dam collapse. The study was carried out at Doce River, in Espírito Santo State, Brazil. Monthly samplings were carried out for a year. Astyanax lacustris had multiple spawning: females reproductive peak was in September, October, November, and December; and males between September, October, January, and February. There was a latency in the formation of gonads. For male gonads, it was necessary a $6 \mathrm{~cm}$ growth for it to increase from $30 \%$ to $50 \%$ and 4 $\mathrm{cm}$ for female gonads to increase from $40 \%$ to $50 \%$. There is a positive correlation between gonad's concentration of $\mathrm{Al}$ and $\mathrm{Fe}$ and the rate of histological damage in females. Male gonads had a high rate of immature cells invading the cell lumen (47.36\%) and female gonads showed higher frequency of atresia (39.64\%). Fish exposed to the contaminated water showed high gonad histological damage. The observed changes can directly influence the organism development and reproduction in the long run, thus affecting $A$. lacustris population present in the region.

\section{Introduction}

On November 5th, 2015, the Fundão dam collapsed in the municipality of Mariana, causing a flood of mud and mining waste (55-62 million $\mathrm{m}^{3}$ ) into the Gualaxo do Norte River. The mud flowed into the Doce River and spread for $600 \mathrm{~km}$ until arriving to the Espírito Santo coast (Escobar 2015). Gomes et al. (2019) and Quadra et al. (2019) reported an increase in several metals in the Doce River shortly after the dam burst. Macêdo et al. (2020) and Weber et al. (2020) observed high concentrations of metals, such as Iron (Fe), Aluminum (Al), Manganese $(\mathrm{Mn})$, and Lead $(\mathrm{Pb})$ in the Doce River, even three years after the dam broke. The presence of these metals in aquatic ecosystems can cause negative impacts on exposed organisms, such as genetic and reproductive damage, reduced growth rate and potentially fatal pathologies (Cantanhêde et al. 2016, Viana et al. 2018). Xenobiotics, such as metals, can act in different pathways in organisms, involving different physiological processes (Tolussi et al. 2018), affecting sexual differentiation (Baroiller and Guiguen 2001) and gonadal development (Vested et al. 2014), and inducing vitellogenin synthesis in males (Vetillard and Bailhache 2006).

Unlike organic pollutants, metals do not suffer degradation or rapid elimination from the ecosystem, causing organisms exposed to these contaminants to accumulate them through the gills or by ingestion through the food chain (Van der Oost et al. 2003; Couture and Pyle 2012; Zeng et al. 2012; Merciai et al. 2015). When ingested, metals bind to the body's molecules such as water, proteins and enzymes, forming stable biotoxic compounds and inactivating biomolecules (Duruibe et al. 2007). These biochemical changes, whether severe or prolonged, can cause structural changes (Hinton and Laurén 1990; Van Dyk et al. 2009) and, thus, cause harmful reproductive effects (James 2011).

Wester and Canton (1992) and Yancheva et al. (2016) state that one of the methodologies that have a direct connection with physiological functions, such as reproduction, is histology. Greenfield et al. (2008) affirm that histological changes in target tissues are sensitive biomarkers for the effects caused by exposure to xenobiotics. These changes occur before phenotypic ones and provide a more in-depth assessment of the effects of water pollution on communities, evaluating the incidence and prevalence of abnormalities in target 
tissues of exposed organisms. Braunbeck et al. (1990) and Yancheva et al. (2016) also state that histological changes are a reflection of the health of the entire population within the ecosystem studied.

Astyanax is one of the most widely distributed fish genera in the Neotropics with around 150 different species (Súarez et al. 2017). The species of Astyanax genera are relatively small (10-12 cm, as an adult). They move in shoals and being important forage specie to fishes in a higher lever of the trophic chain (Pereira et al., 2016). Astyanax lacustris (Lütken 1875) has morphological characteristics that include this species in the group also known as Astyanax bimaculatus. Recently, Lucena and Soares (2016) described Astyanax jacuhiensis, Astyanax asuncionensis and Astyanax altiparanae as synonyms of Astyanax lacustris (Lütken 1875), resulting in a significant expansion in the known distribution of the species. As a result, understanding the species' reproductive biology, and what aspects affect it, has become increasingly important (Súarez et al. 2017). Astyanax lacustris is native to the Doce River and has an early sexual maturity (maturation in 0.7-1.0 years and generations about 18 months old). In addition to its ecological importance, $A$. lacustris is indicated as a sentinel species for environmental investigations in relation to aquatic contamination and experimental tests in the laboratory (Prado et al. 2011), as they have numerous offspring, short generations and are easy to reproduce and manage (Jeffery 2001, Silva and Porto-Foresti 2020). Astyanax lacustris does not migrate for reproduction, has the capacity to reproduce in both lotic and lentic environments, and has a long reproductive period with multiple peaks of active reproduction (Godinho et al. 2010, Weber et al. 2012).

The populations of $A$. lacustris from the Doce River are being exposed to metals throughout their life cycle, due to the environmental disaster that occurred after the Mariana dam collapsed in 2015 (Passos et al., 2020). With the hypothesis that the enrichment of metals in water can negatively influence the reproduction of fish (Kime 1998; Blazer 2002; James 2011), this work aimed to evaluate the reproductive biology of $A$. lacustris in the lower Doce River and to verify the deleterious histological effects of a population chronically exposed to tailings from the dam rupture in November 2015.

\section{Methodology}

\subsection{Fish sampling and biometric measurements}

The Doce River Basin is divided into three physiographic regions. The upper and middle Doce River are located in Minas Gerais, while the lower Doce River is located in Espírito Santo, and it is responsible for approximately one third of the state's water volume (Moretto 2001). Fish and water were sampled in the lower Doce River, downstream of the Mascarenhas Hydroelectric Power Plant (UHE), Baixo Guandu, Espírito Santo State $\left(19^{\circ} 30^{\prime} 04.8\right.$ "S $\left.40^{\circ} 53^{\prime} 23.2^{\prime \prime} \mathrm{W}\right)$, close to the mouth of the Mutum Preto stream (please see graphical abstract). The climate presents pluviometric seasonality with greater rainfall occurring between October and March, with variations from 50 to $300 \mathrm{~mm}$ and an annual total of $1019 \mathrm{~mm}$ (Silva et al. 2010, ANA 2020). In addition, Sales et al. (2018) and ANA (2020) determined that the largest drought occurs from April to September, with an average rainfall of less than $50 \mathrm{~mm}$ per month. The data obtained at the National Water Agency (ANA 2020) come from a pluviometric station (station code: 01941003) located along the course of the river in the municipality of Baixo Guandu.

The project was carried out with the approval of the animal ethics committee (CEUA/UVV \# 563-2018). Monthly samplings of $A$. lacustris were carried out for one year, from June 2018 to May 2019. The fish sampling was 
performed with a 12mm mesh ring net. Between 10 and 20 individuals were sampled monthly (224 individuals at the end of the study) (Table 1).

Table 1

Number of mature, immature and unidentified individuals of $A$. lacustris exposed to the Doce River mining tailings.

\begin{tabular}{|lllllllll|}
\hline Bimesters & Male & \multicolumn{3}{c}{ Female } & N \\
\cline { 2 - 7 } & Mature & Immature & Total & Mature & Immature & Total & \\
\hline Jan Feb & 14 & 9 & 23 & 2 & 5 & 7 & 1 \\
\hline Mar Apr & 5 & 10 & 15 & 12 & 10 & 22 & 0 \\
\hline May Jun & 3 & 13 & 16 & 7 & 15 & 22 & 2 \\
\hline Jul Aug & 9 & 12 & 21 & 5 & 13 & 18 & 7 \\
\hline Sep Oct & 2 & 10 & 12 & 19 & 9 & 28 & 0 \\
\hline Nov Dec & 12 & 6 & 18 & 9 & 3 & 12 & 0 \\
\hline Total & 45 & 60 & 105 & 54 & 55 & 109 & 10 \\
\hline
\end{tabular}

The fish were anesthetized with Benzocaine solution $\left(0.2 \mathrm{~g} . \mathrm{L}^{-1}\right)$ and, afterwards, euthanized by cervical section. For all specimens, sexing was performed based on the presence of spikes in the anal fin of the males and the shape of the body (Dos Santos et al. 2020), with the counterproof being made with the analysis of the gonads. The sex ratio of the population was assessed using the Chi-square test $\left(X_{2}\right)$ with $p<0.05$. Furthermore, measurements of total length ( $T L$ ), body weight (BW) and gonad weight (GW) were taken. Afterwards, the following biological indices were calculated: gonadosomatic index (GSI $=G W \times 100 / B W$ ) and Fulton's condition factor $\left(K=B W \times 100 /\left(T L^{\wedge} 3\right)\right)$. Then, the gonads were removed; a part of them was immersed in glutaraldehyde $0.5 \%$, where they were kept until the histological analysis (Venturoti et al. 2019a, b); the other part was frozen at $-80^{\circ} \mathrm{C}$ for later analysis of metals.

\subsection{Water samplings and analysis}

Monthly water samplings of Doce River (collection site) were carried out in triplicate for physicochemical and metal analysis. The following physicochemical parameters of the water were measured: dissolved oxygen (DO), temperature and pH with the Horiba U53 multiparameter (Tokyo, Japan); and hardness and alkalinity were measured by titration, according to APHA (2005). For metal analysis, the collected water was preserved in nitric acid $(\mathrm{pH}<2)$ for later analysis. $\mathrm{Al}, \mathrm{Cr}, \mathrm{Pb}, \mathrm{Mn}$, and Fe were analyzed, in total fraction, encompassing the metals with toxic potential and evidenced in previous analyses of the Doce River's water and sediment according to Gomes et al. (2017) and Macêdo et al. (2020).

\subsection{Study of gonads}

\subsubsection{Presence and absence of gonads}

The probability of considering A. lacustris individuals capable of reproduction, at a certain body length, was obtained through the presence (visibility of the gonads) or absence (gonads not visible yet) of gonads (Blain and Sutton 2016). The collected fish were separated by size categories, and the number of mature and 
immature individuals in each category was described. Subsequently, the frequency of individuals of each sex with mature gonads was calculated.

The body length estimated at the first maturation $\left(L_{50}\right)$ represents the body length at which $50 \%$ of the fish are in reproductive capacity. The following formula was used to obtain the percentage of growth that the population needs to move from $X \%$ of mature individuals to $50 \%$ of them: Growth percentage $(\%)=(L 50-L X)$ * (100/maximum length of the individuals). For males we used $X=30 \%$ and for females $X=40 \%$, since the smallest individuals collected presented $30 \%$ and $40 \%$ of the population already sexually matured for males and females, respectively.

\subsubsection{Histological analysis of gonadal maturation}

For histological analysis, the gonads were prepared according to Venturoti et al. (2019a, b): (I) dehydration of gonad samples with increasing concentrations of alcohol, reaching 100\% (overnight); (II) infiltration of gonad samples with historesin solution (Historesin kit, LEICA Biosystems, Wetzlar, DE); (III) histological section of the gonads (5 $\mu \mathrm{m}$ thick), using a microtome (LEICA model - RM2125RT); (IV) slide staining with hematoxylin-eosin (HE). Afterwards, the stages of gonadal development were classified according to Prado et al. (2011) using a microscope (Leica Galen III model). The stages description of the gonadal development is detailed in the supplementary material (Table 2).

Table 2

Microscopic characteristics of the gonadal maturation stages of $A$. lacustris organisms exposed to Rio Doce mining tailings.

\begin{tabular}{|lll|}
\hline & Machos & Female \\
\hline Resting (1) & $\begin{array}{l}\text { Seminiferous tubules with only sperm and } \\
\text { occlused lumen. }\end{array}$ & $\begin{array}{l}\text { Presence of early and advanced perinuclear } \\
\text { follicles and oogony nests. }\end{array}$ \\
\hline $\begin{array}{l}\text { Maturation } \\
(2)\end{array}$ & $\begin{array}{l}\text { Seminiferous tubules with sperm cell cysts } \\
\text { and lumen full of sperm and acidophilic } \\
\text { secretion. }\end{array}$ & $\begin{array}{l}\text { Presence of perinuclear follicles, pre- } \\
\text { vitellogenic follicles and vitelogenic follicles. }\end{array}$ \\
\hline $\begin{array}{l}\text { Parcial } \\
\text { spawning } \\
(3)\end{array}$ & $\begin{array}{l}\text { Presence of few sperm cell cysts and } \\
\text { partially empty tubular lumen. }\end{array}$ & $\begin{array}{l}\text { Presence of perinuclear follicles, pre- } \\
\text { vitellogenic follicles, vitelogenic follicles and } \\
\text { post-ovulatory follicles. }\end{array}$ \\
\hline $\begin{array}{l}\text { Total } \\
\text { spawning } \\
(4)\end{array}$ & $\begin{array}{l}\text { Seminiferous tubules containing } \\
\text { spermatogonia and empty tubular lumen } \\
\text { with only a few remnants of sperm. }\end{array}$ & $\begin{array}{l}\text { Presence of perinuclear follicles and post- } \\
\text { ovulatory follicles. }\end{array}$ \\
\hline
\end{tabular}

\subsubsection{Histological damage to the gonad}

For both sexes, 8 gonad sections from each individual were read microscopically. A qualitative histological analysis was performed using a microscope. After this procedure, the results were transformed, in a semiquantitative way, using a protocol according to Agbohessi et al. (2015). Also, according to Agbohessi et al. (2015), the score and the importance factor for each alteration identified were multiplied and then added in order to obtain the gonad damage index of each individual. According to Bernet et al. (1999) and Agbohessi et al. (2015), the formula used to calculate these indices was: ${ }^{I_{\text {org }}}=\sum_{r p} \sum_{a l t}\left(\alpha\right.$ org rp alt $\left.\times \omega_{\text {org rp alt }}\right)$, where org $=$ organ (constant), $r p=$ reaction pattern, alt = alteration, $a=$ score and $\omega=$ importance factor. 
For females, the histological analysis and damage index determination was also carried out quantitatively. For this, a reading of all cells and all cuts was made. The numerical data obtained were later transformed into a percentage of damage (Prado et al. 2011).

These indices were used to compare the severity of each histological alteration found in the collected fish. To classify the severity of the damage index in the testicles (It) and the damage index in the ovaries (lo), the results were evaluated based on a classification system provided by Agbohessi et al. (2015): Class 1 (index < 10): tissue with normal structure and few histological changes; Class 2 (index 10-20): tissue with normal structure and moderate histological changes; Class 3 (index 20-30): clear changes in organ tissue; Class 4 (index $>30$ ): severe changes in organ tissue. In order to determine the severity index of each individual, the changes described in Table 3 were accounted for.

In addition to the indices calculated by score and pathological importance of the lesions, another point of interest was used for histopathological characteristics (Agbohessi et al. 2015). The prevalence of each change was calculated according to the percentage of occurrence among the collected fish. The formula used was: Prevalence of histological changes $=($ Number of fish with the change $/$ Total number of fish) $\times 100$ (Agbohessi et al. 2015).

Table 3

List of histological changes detected microscopically in individuals of A. lacustris exposed to mining waste from Rio Doce.

\begin{tabular}{|c|c|}
\hline Alteration & Description \\
\hline & Female \\
\hline Atresia & $\begin{array}{l}\text { Agglomeration or perforation of the radiated area, fragmentation of the nucleus, } \\
\text { disorganization of the ooplasm and reabsorption of the yolk by the perifollicular cells }\end{array}$ \\
\hline Hyperplasia & Increase in the number of cells in the epithelium involved in follicular development \\
\hline \multirow[t]{2}{*}{$\begin{array}{l}\text { Basal } \\
\text { membrane } \\
\text { detachment }\end{array}$} & $\begin{array}{l}\text { When the cytoplasm recedes and detaches from the epithelium involved in follicular } \\
\text { development }\end{array}$ \\
\hline & Male \\
\hline $\begin{array}{l}\text { Immature cells } \\
\text { invading lumen }\end{array}$ & $\begin{array}{l}\text { It occurs when cells of primary development, such as spermatogonia, invade the lumen, } \\
\text { staying between the spermatozoa }\end{array}$ \\
\hline Intersex & $\begin{array}{l}\text { Presence of one or more oogenic cells (individual or clustered), between the testicular } \\
\text { cells. However, they are perinuclear, cortical alveoli, vitellogenic or attractive. There is no } \\
\text { evidence of ovarian architecture }\end{array}$ \\
\hline $\begin{array}{l}\text { Desynchronized } \\
\text { growth }\end{array}$ & Presence of more than one stage of sperm cell development in a single gonad cut \\
\hline
\end{tabular}

\subsection{Metal analysis}

The concentrations of metals in water and gonads were measured. For digestion of the gonads, ultrapure water, ultrapure nitric acid, and hydrogen peroxide (5:2:1) and a microwave energy digester (Ethos UP from Millestone) were used. We followed the protocol of the device for digestion: $30 \mathrm{~min}$ at $200^{\circ} \mathrm{C}$ and maximum power of $1000 \mathrm{~W}$. After being digested, the samples were quantified for $\mathrm{Al}, \mathrm{Cr}, \mathrm{Pb}, \mathrm{Mn}$, and $\mathrm{Fe}$ in a graphite oven, in the Atomic 
Absorption spectrophotometer (Thermo ICE3500). The quality assurance and quality control (QA/QC) tests of the analyses were carried out in order to monitor and control the reliability of the analysis methodology. For each evaluated metal, a calibration curve was prepared and for Fe and $\mathrm{Mn}$, a certified reference material (ERM ${ }^{\circledR}$ - BB422) was used (Table 4). The bioconcentration factor of each metal was also calculated, relating the concentration of metals in the water and in the gonad of each fish, using the following formula: $B C F=C g / C w$, where $\mathrm{Cg}$ is the concentration of the metal in the gonad of each organism and $\mathrm{CW}$ is the metal concentration in the collected water (Nenciu et al. 2016). According to the Registration, Evaluation, Authorization and Restriction of Chemicals, a regulation of the European Parliament (REACH \# 1907/2006), a metal fulfils the bioaccumulation criterion when BCF > 2000. As for the United States Environmental Protection Agency (USEPA), a metal is considered a trigger for potential bioaccumulative effects when BCF $>1000$. When BCF $>5000$, the metal is considered highly bioaccumulative for both REACH and USEPA.

Table 4

Percentage of recovery of analytes present in the certified reference material (ERM-BB422), limits of quantification and detection practicable (mg. $\mathrm{kg}^{-1}$ wet weight), limits of detection and limit of quantification of analytes.

\begin{tabular}{|lllllll|}
\hline Metal & $\begin{array}{l}\text { Certified values } \\
(\mathbf{m g} / \mathbf{k g})\end{array}$ & $\begin{array}{l}\text { Measured values } \\
(\mathbf{m g} / \mathbf{k g})\end{array}$ & $\begin{array}{l}\text { Recovery } \\
(\%)\end{array}$ & $\begin{array}{l}\text { LD } \\
(\mu \mathrm{g} / \mathrm{L})\end{array}$ & $\begin{array}{l}\text { LQ } \\
(\boldsymbol{\mu g} / \mathrm{L})\end{array}$ & $\mathrm{R}^{2}$ \\
\hline $\mathrm{Al}$ & - & - & - & 40,473 & 122,65 & 0,99 \\
\hline $\mathrm{Cr}$ & - & - & - & 10,945 & 33,168 & 0,99 \\
\hline $\mathrm{Mn}$ & 0,37 & 0,44 & 118 & 6,730 & 20,396 & 0,99 \\
\hline $\mathrm{Fe}$ & 9,4 & 9,9 & 105 & 44,035 & 133,44 & 0,99 \\
\hline $\mathrm{Pb}$ & - & - & - & 0,420 & 1,274 & 0,99 \\
\hline
\end{tabular}

\subsection{Statistical Analysis}

The results of metal concentration in the water quality were grouped every two months and presented as mean and standard error. The results of metal concentration in the gonad were also grouped every two months, but it was presented as mean and standard deviation. The concentration of the different metals in the gonads was compared - between sexes and bimonthly - by a two factor ANOVA $(p<0.05)$, followed by a Tukey test $(p<$ 0.05). The values were logarithmic (Log 10) in order to normalize the results. The GSI and FC were compared between bimesters by ANOVA $(p<0.05)$, followed by a Tukey test $(p<0.05)$.

To determine the correlation between the histological damage index and quantification of metals in the gonad, a Pearson correlation was performed $(p<0.05)$.

\section{Results}

\subsection{Physicochemical and metal analysis in water}

The results of the physicochemical parameters and the concentrations of $\mathrm{Fe}, \mathrm{Mn}, \mathrm{Al}, \mathrm{Cr}$, and $\mathrm{Pb}$ in water are described in Table 5. Dissolved oxygen obtained an average of $7.71 \pm 0.34 \mathrm{mg} . \mathrm{L}^{-1}$, with a higher concentration in May and June, and, lower, in November and December. We obtained a temperature average of $27.09 \pm 1.54{ }^{\circ} \mathrm{C}$, 
with higher detection in January and February, and, lower, in July and August, following the temperature of the seasons. We obtained the same results for $\mathrm{pH}$ and alkalinity, with higher results in May and June $(7.37 \pm 0.02$ and $80.9 \pm 3.75 \mathrm{mg} . \mathrm{L}^{-1}$, respectively) and, lower, in November and December (5.21 \pm 0.11 and $36.35 \pm 3.22$ $\mathrm{mg} . \mathrm{L}^{-1}$, respectively). The average $\mathrm{pH}$ was $6.59 \pm 0.29$ and the alkalinity was $66.33 \pm 4.38 \mathrm{mg} . \mathrm{L}^{-1}$. We obtained a conductivity average of $66.33 \pm 0.007 \mu \mathrm{g} . \mathrm{cm}^{-1}$, with higher results in May and June, and, lower, in July and August. This also occurred with hardness, which showed higher results in July and August and lower in September and October. The average hardness was $44.21 \pm 1.26 \mathrm{mg} \cdot \mathrm{L}^{-1}$. In relation to metals, the ones with the highest concentration were $\mathrm{Al}$ and $\mathrm{Fe}$, with averages of $543.78 \pm 125.58 \mu \mathrm{g} . \mathrm{L}^{-1}$ and $491.59 \pm 97.36 \mu \mathrm{g} . \mathrm{L}^{-1}$, respectively. Al was found in greater concentration in January and February, with $986.83 \pm 237.08 \mu \mathrm{g} \cdot \mathrm{L}^{-1}$; and Fe was found in greater concentration in November and December, with $900.88 \pm 131.78 \mu \mathrm{g} . \mathrm{L}^{-1}$, both in the period of greatest rainfall (Sales et al. 2018). The concentration of metals in the water during the sampling followed the following order: Jan Feb (Al $>\mathrm{Fe}>\mathrm{Mn}>\mathrm{Pb}>\mathrm{Cr})$, Mar Apr ( $\mathrm{Al}>\mathrm{Fe}>\mathrm{Mn}>\mathrm{Cr}>\mathrm{Pb})$, May Jun $(\mathrm{Fe}>\mathrm{Al}>\mathrm{Mn}>\mathrm{Cr}>$ $\mathrm{Pb})$, Jul Aug (Al $>\mathrm{Fe}>\mathrm{Mn}>\mathrm{Pb}>\mathrm{Cr})$, Sep Oct $(\mathrm{Al}>\mathrm{Cr}>\mathrm{Mn}>\mathrm{Fe}>\mathrm{Pb})$, and Nov $\mathrm{Dec}(\mathrm{Cr}>\mathrm{Al}>\mathrm{Mn}>\mathrm{Pb}>\mathrm{Fe})$. 
Table 5

Annual physicochemical parameters and concentration of metals quantified in the Doce River. The data are presented as mean and standard error. $\angle \mathrm{LQ}=$ below the limit of quantification.

\begin{tabular}{|c|c|c|c|c|c|c|}
\hline \multirow[t]{2}{*}{ Parameters } & \multicolumn{6}{|l|}{ Bimesters } \\
\hline & Jan Feb & Mar Apr & May Jun & Jul Aug & Sep Oct & Nov Dec \\
\hline $\begin{array}{l}\text { Dissolved oxygen } \\
\left(\mathrm{mg} . \mathrm{L}^{-1}\right)\end{array}$ & $7.71 \pm 0.68$ & $7.40 \pm 0.23$ & $\begin{array}{l}8.90 \pm \\
0.15\end{array}$ & $7.74 \pm 0.15$ & $7.73 \pm 0.83$ & $6.77 \pm 0.03$ \\
\hline Temperature $\left({ }^{\circ} \mathrm{C}\right)$ & $\begin{array}{l}30.81 \pm \\
1.27\end{array}$ & $\begin{array}{l}27.06 \pm \\
2.43\end{array}$ & $\begin{array}{l}27.04 \pm \\
1.97\end{array}$ & $\begin{array}{l}24.46 \pm \\
0.14\end{array}$ & $\begin{array}{l}25.64 \pm \\
0.95\end{array}$ & $\begin{array}{l}27.51 \pm \\
2.48\end{array}$ \\
\hline $\mathrm{pH}$ & $7.41 \pm 0.15$ & $6.55 \pm 0.41$ & $\begin{array}{l}7.37 \pm \\
0.02\end{array}$ & $6.93 \pm 0.09$ & $6.06 \pm 0.97$ & $5.21 \pm 0.11$ \\
\hline $\begin{array}{l}\text { Conductivity } \\
\left(\mu \mathrm{s} . \mathrm{cm}^{-1}\right)\end{array}$ & $\begin{array}{l}60.00 \pm \\
0.02\end{array}$ & $\begin{array}{l}65.00 \pm \\
0.010\end{array}$ & $\begin{array}{l}101.00 \pm \\
0.008\end{array}$ & $\begin{array}{l}54.00 \pm \\
0.002\end{array}$ & $\begin{array}{l}57.00 \pm \\
0.001\end{array}$ & $\begin{array}{l}61.00 \pm \\
0.001\end{array}$ \\
\hline $\begin{array}{l}\text { Hardness (mg. } \mathrm{L}^{-} \\
\left.{ }^{1}\right)\end{array}$ & $\begin{array}{l}35.48 \pm \\
2.95\end{array}$ & $\begin{array}{l}53.68 \pm \\
0.53\end{array}$ & $\begin{array}{l}36.67 \pm \\
0.38\end{array}$ & $\begin{array}{l}65.56 \pm \\
0.50\end{array}$ & $\begin{array}{l}34.49 \pm \\
1.45\end{array}$ & $\begin{array}{l}39.38 \pm \\
1.78\end{array}$ \\
\hline $\begin{array}{l}\text { Alkalinity (mg. } L^{-} \\
\left.{ }^{1}\right)\end{array}$ & $\begin{array}{l}39.59 \pm \\
1.51\end{array}$ & $\begin{array}{l}53.32 \pm \\
5.35\end{array}$ & $\begin{array}{l}80.9 \pm \\
3.75\end{array}$ & $43.4 \pm 5.62$ & $\begin{array}{l}46.00 \pm \\
6.85\end{array}$ & $\begin{array}{l}36.35 \pm \\
3.22\end{array}$ \\
\hline $\mathrm{Al}\left(\mu \mathrm{g} . \mathrm{L}^{-1}\right)$ & $\begin{array}{l}986.83^{ \pm} \\
237.08^{a}\end{array}$ & $\begin{array}{l}840.26 \pm \\
202.77^{a}\end{array}$ & $\begin{array}{l}284.15 \pm \\
43.32^{b}\end{array}$ & $\begin{array}{l}204.13 \pm \\
57.02^{b}\end{array}$ & $\begin{array}{l}289.70 \pm \\
65.59^{b}\end{array}$ & $\begin{array}{l}657.63 \pm \\
147.69 \mathrm{ab}\end{array}$ \\
\hline $\operatorname{Cr}\left(\mu \mathrm{g} . \mathrm{L}^{-1}\right)$ & $\begin{array}{l}0.42 \pm 0.08 \\
c\end{array}$ & $\begin{array}{l}0.83 \pm 0.12 \\
b\end{array}$ & $\begin{array}{l}5.86 \pm \\
0.11^{a}\end{array}$ & $\begin{array}{l}3.58 \pm 0.85 \\
a\end{array}$ & $\begin{array}{l}0.24 \pm 0.48 \\
c\end{array}$ & $\begin{array}{l}0.76 \pm 0.05 \\
b\end{array}$ \\
\hline $\mathrm{Fe}\left(\mu \mathrm{g} \cdot \mathrm{L}^{-1}\right)$ & $\begin{array}{l}724.80 \pm \\
164.01^{\mathrm{ab}}\end{array}$ & $\begin{array}{l}685.32 \pm \\
101.35^{a b}\end{array}$ & $\begin{array}{l}308.18 \pm \\
92.52 \text { bc }\end{array}$ & $\begin{array}{l}155.07 \pm \\
46.09^{c}\end{array}$ & $\begin{array}{l}175.32 \pm \\
48.40^{c}\end{array}$ & $\begin{array}{l}900.88^{ \pm} \\
131.78^{a}\end{array}$ \\
\hline $\operatorname{Mn}\left(\mu \mathrm{g} \cdot \mathrm{L}^{-1}\right)$ & $\begin{array}{l}75.82 \pm \\
18.38^{a}\end{array}$ & $\begin{array}{l}64.70 \pm \\
8.43^{a b}\end{array}$ & $\begin{array}{l}29.33 \pm \\
16.05^{a b}\end{array}$ & $\begin{array}{l}22.42 \pm \\
7.97^{b}\end{array}$ & $\begin{array}{l}23.83 \pm \\
8.47^{a b}\end{array}$ & $\begin{array}{l}76.18 \pm \\
17.37^{a}\end{array}$ \\
\hline $\mathrm{Pb}\left(\mu \mathrm{g} \cdot \mathrm{L}^{-1}\right)$ & $\begin{array}{l}0.002 \pm \\
0.001^{a}\end{array}$ & $\begin{array}{l}0.0002 \pm \\
0.0001^{a}\end{array}$ & $\begin{array}{l}0.0012 \pm \\
0.001^{a}\end{array}$ & $\begin{array}{l}0.00001 \pm \\
0.0001^{a}\end{array}$ & $\begin{array}{l}0.0001 \pm \\
0.00001^{a}\end{array}$ & $\begin{array}{l}0.001 \pm \\
0.001\end{array}$ \\
\hline
\end{tabular}

\subsection{Biological indices and sexual maturation}

A total of 105 males and 109 females were collected, and no significant differences were found in the sex ratio of the population $\left(X_{2}=0.075 ; \mathrm{gl}=1 ; \mathrm{p}=0.78\right)$. The average male weight was $9.14 \pm 3.81 \mathrm{~g}$, with a variation between 4.02 and $27.32 \mathrm{~g}$; and the average length was $8.46 \pm 1.44 \mathrm{~cm}$, with a variation between 5.1 and 16.6 $\mathrm{cm}$. The average weight of the females was $11.89 \pm 6.44 \mathrm{~g}$, with a variation between 4.92 and $40.3 \mathrm{~g}$; and the average length was $9.27 \pm 1.75 \mathrm{~cm}$, with a variation between 7.0 and $17.4 \mathrm{~cm}$.

Males obtained 30\% gonadal maturation with $5 \mathrm{~cm}$ in length and $50 \%$ gonadal maturation with $11 \mathrm{~cm}$ in length. Between obtaining $30 \%$ of matured organisms and $50 \%$ of matured organisms, male fish had to grow $35.29 \%$ in relation to their maximum size. Females obtained $40 \%$ of gonadal maturation at $7 \mathrm{~cm}$ in length and $50 \%$ of gonadal maturation at $11 \mathrm{~cm}$ in length. Thus, between $30 \%$ and $50 \%$ of matured organisms, females needed to grow 22.22\% (Table 6). 
Table 6

Sexual maturation of $A$. lacustris, exposed to the Doce River mining tailings, in different length classes $(\mathrm{cm}) . \mathrm{M}=$ frequency of mature individuals in each length.

\begin{tabular}{|c|c|c|c|c|c|c|c|c|}
\hline \multirow{2}{*}{$\begin{array}{l}\text { Size } \\
(\mathrm{cm})\end{array}$} & \multicolumn{4}{|c|}{ Male } & \multicolumn{4}{|c|}{ Female } \\
\hline & $n$ & Immature & Mature & M (\%) & $\mathrm{n}$ & Immature & Mature & $M(\%)$ \\
\hline $5-6$ & 3 & 2 & 1 & 33.3 & 0 & - & - & - \\
\hline $6.1-7$ & 8 & 5 & 3 & 37.5 & 0 & - & - & - \\
\hline $7.1-8$ & 34 & 22 & 12 & 35.3 & 33 & 20 & 13 & 39.9 \\
\hline $8.1-9$ & 28 & 17 & 11 & 39.3 & 26 & 15 & 11 & 42.3 \\
\hline $9.1-10$ & 19 & 8 & 11 & 57.9 & 22 & 9 & 13 & 59.1 \\
\hline $10.1-11$ & 6 & 3 & 3 & 50 & 15 & 7 & 8 & 53.3 \\
\hline $11.1-12$ & 2 & 1 & 1 & 50 & 8 & 3 & 5 & 62.5 \\
\hline $12.1-13$ & 0 & - & - & - & 3 & 0 & 3 & 100 \\
\hline $13.1-14$ & 0 & - & - & - & 2 & 0 & 2 & 100 \\
\hline $14.1-15$ & 0 & - & - & - & 1 & 1 & 0 & 0.0 \\
\hline $15.1-16$ & 0 & - & - & - & 0 & - & - & - \\
\hline $16.1-17$ & 1 & 0 & 1 & 100 & 0 & - & - & - \\
\hline $17.1-18$ & 0 & - & - & - & 1 & 0 & 1 & 100 \\
\hline
\end{tabular}

Males had a lower number of gonads at peak maturation (stage 2) in May Jun and Jul Aug, with 0\% and 40\%, respectively. Jan Feb showed $100 \%$ of gonads at peak maturation, being considered the main months of male reproduction. Jul Aug and Sep Oct were the only months that presented gonads in the process of total spawning (stage 4), with $20 \%$ and $50 \%$, respectively. Despite this, the same months also showed gonads at peak maturation (40\% and 50\%, respectively). Females had a higher reproduction rate in Sep Oct and Nov Dec, with a greater number of gonads at peak maturation (65\% and $45 \%$, respectively), even though they also had partial spawning gonads (stage 3 ) (35\% and 55\%, respectively). In addition, May Jun showed $100 \%$ of cells in total spawning and Jan Feb showed $100 \%$ of cells in partial spawning. The main peak of maturation of females occurred in Sep Oct, despite having cells that matured in other months of the year. This proves the capacity for intermittent reproduction of the species A. lacustris (Fig. 1a).

The GSI of males and females were proportional over the months. Both had an GSI peak in Sep Oct and lower levels of GSI in Mar Apr. The GSI of the males showed a significant difference only between Mar Apr and Nov $\operatorname{Dez}(p=0.02)$. For females, there was a significant difference when comparing the months of Nov Dec with Mar Apr $(p<0.001)$ and with May Jun $(p=0.003)$. Sep Oct also showed a significant difference when compared to Mar Apr ( $<0.001)$ and May Jun $(p=0.002)$. In addition, Jul Aug showed a significant difference when compared to Mar Apr, with $p=0.015$ (Fig. 1b). The Fulton condition factor (K), determinant of body condition or 
wellbeing of the organism, remained constant in both sexes, with $\mathrm{K}$ ranging from 1.3 to 1.6 for males and from 1.2 to 1.6 for females (Fig. 1c).

\subsection{Concentration of metals in the gonads}

Both males and females showed higher concentrations of $\mathrm{Al}$ and $\mathrm{Fe}$ in their gonads, in relation to $\mathrm{Cr}$, $\mathrm{Mn}$ and $\mathrm{Pb}$ (Fig. 2). In relation to $\mathrm{Al}, \mathrm{Cr}$, Fe and $\mathrm{Pb}$, males bioaccumulated significantly higher concentrations than females. When comparing the concentrations between sexes in relation to Al, there was a significant difference in Jan Feb $(p=0.043)$ and Sep Oct $(p=0.018)$. When Al concentrations were analyzed only between males and females, separately, we found a significant difference for males between May Jun and Sep Oct, with $p=0.006$. Females also showed significant difference between May Jun and Sep Oct with $p=0.016$. Cr bioaccumulation showed a significant difference between sexes in Jan Feb, with $p=0.010$, and Sep Oct with $p=0.011$. When comparing the concentrations between males and females separately, there was no significant difference between the bimesters. Fe showed a significant difference when comparing the concentration between males and females only in Sep Oct, with $p=0,039$. In relation to $\mathrm{Mn}$, a significant difference was observed between the sexes in Nov Dec ( $p=0.004)$; and, when analyzing the concentrations in males and females separately, the difference was observed only in males, when comparing Nov Dec with May Jun and Jul Aug ( $p=0.044$ and $p=$ 0.032 , respectively). Concentrations of $\mathrm{Pb}$, when compared between sexes, showed a significant difference between Sep Oct, with $p=0.023$, and Nov Dec, with $p=0.041$. When males and females were compared separately, there was no significant difference between the bimesters.

Despite having a higher concentration of $\mathrm{Al}$ in the gonads, the BCF of the metals followed the following order for males: Jan Feb ( $\mathrm{Cr}>\mathrm{Pb}>\mathrm{Mn}>\mathrm{Al}>\mathrm{Fe})$, Mar Apr ( $\mathrm{Cr}>\mathrm{Mn}>\mathrm{Al}>\mathrm{Fe}>\mathrm{Pb})$, May Jun ( $\mathrm{Cr}>\mathrm{Fe}>\mathrm{Mn}>\mathrm{Al}>\mathrm{Pb})$, Jul Aug $(\mathrm{Cr}>\mathrm{Al}>\mathrm{Pb}>\mathrm{Mn}>\mathrm{Fe})$, Sep Oct $(\mathrm{Cr}>\mathrm{Al}>\mathrm{Mn}>\mathrm{Pb}>\mathrm{Fe})$, and Nov Dec $(\mathrm{Cr}>\mathrm{Mn}>\mathrm{Pb}>\mathrm{Al}>\mathrm{Fe})$, being Cr the metal with the highest BCF (Table 7). For females, the BCF of the metals followed the following order: Jan Feb ( $\mathrm{Cr}>\mathrm{Pb}$ $>\mathrm{Mn}>\mathrm{Al}>\mathrm{Fe})$, Mar Apr ( $\mathrm{Cr}>\mathrm{Mn}>\mathrm{Al}>\mathrm{Fe}>\mathrm{Pb})$, May Jun $(\mathrm{Mn}>\mathrm{Cr}>\mathrm{Fe}>\mathrm{Al}>\mathrm{Pb})$, Jul Aug $(\mathrm{Cr}>\mathrm{Al}>\mathrm{Mn}>\mathrm{Pb}>\mathrm{Fe})$, Sep Oct $(\mathrm{Cr}>\mathrm{Al}>\mathrm{Mn}>\mathrm{Pb}>\mathrm{Fe})$, and Nov $\mathrm{Dec}(\mathrm{Cr}>\mathrm{Pb}>\mathrm{Mn}>\mathrm{Al}>\mathrm{Fe})$. Al presented a BCF with potential bioaccumulative effects by REACH and TSCA only in Jul Aug (BCF = 2,167.68). On the other hand, Cr had potentially bioaccumulative BCF in all months, except for May Jun, with BCF $=120$. Jan Feb months showed highly bioaccumulative effects, with $\mathrm{BCF}=10,027.23$. Fe, $\mathrm{Mn}$ and $\mathrm{Pb}$ did not present values considered potentially bioaccumulative in any of the bimesters, with $\mathrm{BCF}<1000$. 
Table 7

Bioconcentration factor (BCF) of $A$. lacustris

exposed to the mining tailings from the Doce River

water along the bimesters. (-) indicates that the

formula could not be applied due to water values <

LQ.

\begin{tabular}{|c|c|c|c|c|c|}
\hline \multirow[t]{2}{*}{ Sex } & \multicolumn{5}{|c|}{ Bioconcentration factor } \\
\hline & Al & $\mathrm{Cr}$ & $\mathrm{Fe}$ & Mn & $\mathrm{Pb}$ \\
\hline \multicolumn{6}{|l|}{ Jan Feb } \\
\hline Male & 59 & 10027 & 12 & 141 & 192 \\
\hline Female & 14 & 1956 & 2 & 41 & 111 \\
\hline \multicolumn{6}{|l|}{ Mar Apr } \\
\hline Male & 39 & 4343 & 16 & 62 & - \\
\hline Female & 223 & 5529 & 205 & 396 & - \\
\hline \multicolumn{6}{|c|}{ May Jun } \\
\hline Male & 25 & 120 & 89 & 85 & - \\
\hline Female & 3 & 13 & 9 & 281 & - \\
\hline \multicolumn{6}{|l|}{ Jul Aug } \\
\hline Male & 2168 & 3665 & 424 & 51 & 441 \\
\hline Female & 655 & 261 & 100 & 48 & 256 \\
\hline \multicolumn{6}{|l|}{ Sep Out } \\
\hline Male & 743 & 8907 & 375 & 462 & - \\
\hline Female & 193 & 3457 & 104 & 137 & - \\
\hline \multicolumn{6}{|c|}{ Nov Dec } \\
\hline Male & 119 & 3306 & 14 & 773 & 463 \\
\hline Female & 70 & 1220 & 6 & 71 & 868 \\
\hline
\end{tabular}

\subsection{Histological damage to the gonads}

Six types of changes, all classified as deleterious changes (DC), were identified in the fish collected in the Doce River. In males, the greatest amount of damage was found in Jul Aug. The invasion of immature cells into the lumen had a higher prevalence in Jan-Feb, May Jun and Jul Aug (100\% each) and lower prevalence in Sep Oct, with presence of $50 \%$ of damage to the organisms. Intersex was present in Jul Aug and Nov Dec, with $20 \%$ and $16.66 \%$ prevalence, respectively, in the collected organisms. As for the detection of desynchronized maturation processes in the same gonad, a higher prevalence was detected in Jan Feb, May Jun and Sep Oct (100\%), and a lower prevalence in Nov Dec, with 66.66\%. 
In females, atresia had the highest prevalence among the collected fish. Only Mar Apr and May Jun had a prevalence of less than $100 \%$, with May Jun having a prevalence of $0 \%$. Hyperplasia had $100 \%$ prevalence in Jan Feb and Nov Dec. Mai Jun also had a prevalence of $0 \%$. Membrane detachment showed a prevalence of $100 \%$ only in Jan Feb. May Jun also had a prevalence of $0 \%$, being the months with the lowest rate of gonadal damage (Table 8).

Table 8

Prevalence (\%) of the histopathological changes observed in the A. lacustris gonads exposed to the Doce River mining tailings. The importance factor is indicated in parentheses in each change. $\mathrm{DC}=$ deleterious changes; IS $=$ Intersex

\begin{tabular}{|cllllllll|}
\hline Organs & $\begin{array}{l}\text { Reaction } \\
\text { pattern }\end{array}$ & Alteration & $\begin{array}{l}\text { Jan } \\
\text { Feb }\end{array}$ & $\begin{array}{l}\text { Mar } \\
\text { Apr }\end{array}$ & $\begin{array}{c}\text { May } \\
\text { Jun }\end{array}$ & $\begin{array}{c}\text { Jul } \\
\text { Aug }\end{array}$ & $\begin{array}{c}\text { Sep } \\
\text { Oct }\end{array}$ & $\begin{array}{l}\text { Nov } \\
\text { Dec }\end{array}$ \\
\hline Testes & DC & $\begin{array}{l}\text { Immature cells invading the } \\
\text { lumen (2) }\end{array}$ & 100 & 75 & 100 & 100 & 50 & 83.3 \\
& DC & Desynchronized growth (3) & 100 & 75 & 100 & 20 & 100 & 33.3 \\
& IS & Intersex (3) & 0 & 0 & 0 & 20 & 0 & 16.7 \\
\hline Ovarian & DC & Atresia (3) & 100 & 85.7 & 0 & 100 & 100 & 100 \\
\hline & DC & Hyperplasia (2) & 100 & 85.7 & 0 & 60 & 90.9 & 100 \\
\hline & DC & Membrane detachment (1) & 100 & 42.9 & 0 & 20 & 54.5 & 85.7 \\
\hline
\end{tabular}

Regarding semi-quantitative analyses, the same protocol was used to determine the classes of testicular and ovarian changes. Males showed moderate histological damage (Class 2) in all periods, except in Jul Aug, in which they presented clear histological damage (Class 3). Females also presented moderate histological damage (Class 2) in all periods, except for May Jun, in which they presented little histological damage (Class 1), and Nov Dec, in which they presented clear histological damage (Class 3). When all individuals were analyzed, without separation by periods, both sexes obtained, on average, moderate levels of histological damage (Table 8).

Pearson correlation $(p<0.05)$ was performed in order to identify which metals had direct interference in the damage levels of males and females and, in a semi-quantitative way, no significant difference was identified (Table 9). 
Table 9

Histological damage index (qualitative and quantitative), class and Pearson's correlation (CP) of $A$. lacustris organisms exposed to the Doce River mining tailings. The data are presented as mean and standard error. Significant values are shown in bold.

\begin{tabular}{|c|c|c|c|c|c|}
\hline Sex & \multicolumn{2}{|l|}{ Index } & Class & \multicolumn{2}{|l|}{$\mathbf{N}$} \\
\hline \multicolumn{6}{|c|}{ Qualitative analysis } \\
\hline Male & \multicolumn{2}{|l|}{$16 \pm 1.68$} & 2 & \multicolumn{2}{|l|}{21} \\
\hline Female & \multicolumn{2}{|l|}{$17.24 \pm 1.45$} & 2 & \multicolumn{2}{|l|}{28} \\
\hline \multicolumn{6}{|c|}{ Quantitative analysis } \\
\hline Female & \multicolumn{2}{|l|}{$23.41 \pm 2.75$} & 3 & \multicolumn{2}{|l|}{28} \\
\hline \multicolumn{6}{|c|}{ Pearson correlation $(p<0,05)$} \\
\hline \multicolumn{6}{|c|}{ Qualitative analysis } \\
\hline & Al & $\mathrm{Cr}$ & $\mathrm{Fe}$ & $\mathrm{Mn}$ & $\mathrm{Pb}$ \\
\hline \multirow[t]{2}{*}{ Male } & $C P=0.09$ & $C P=-0.04$ & $C P=0.12$ & $\mathrm{CP}=0.14$ & $C P=-0.09$ \\
\hline & $p=0.68$ & $p=0.84$ & $p=0.68$ & $p=0.55$ & $p=0.71$ \\
\hline \multirow[t]{2}{*}{ Female } & $C P=-0.003$ & $\mathrm{CP}=0.15$ & $\mathrm{CP}=0.02$ & $C P=-0.10$ & $C P=0.20$ \\
\hline & $p=0.98$ & $p=0.42$ & $p=0.90$ & $p=0.57$ & $p=0.27$ \\
\hline \multicolumn{6}{|c|}{ Pearson correlation $(p<0,05)$} \\
\hline \multicolumn{6}{|c|}{ Quantitative analysis } \\
\hline & Al & $\mathrm{Cr}$ & $\mathrm{Fe}$ & $\mathrm{Mn}$ & $\mathrm{Pb}$ \\
\hline \multirow[t]{2}{*}{ Female } & $C P=0.37$ & $\mathrm{CP}=0.08$ & $\mathrm{CP}=0.41$ & $C P=-0.12$ & $C P=-0.001$ \\
\hline & $p=0.04$ & $p=0.88$ & $p=0.03$ & $p=0.81$ & $p=1.00$ \\
\hline
\end{tabular}

Females were also analyzed quantitatively. When compared, the period with the highest damage rate was Jan Feb, with $54.62 \%$ of damaged cells. This result classified this period as Class 4 of histological damage (severe changes). The period with the lowest percentage of damage was May Jun, with $0.96 \%$ of damaged cells (Class 1 ). The average rate of damage to the female gonads was 23.41, thus classifying the female gonads as Class 3 of histological damage. When a Pearson correlation was made between metals and quantitative damage analysis, there was a positive correlation in relation to $\mathrm{Al}(\mathrm{p}=0.04, \mathrm{CP}=0.37)$, only.

\section{Discussion}

\subsection{Physicochemical and metal analysis in water}

Previous studies, such as the one by Escobar (2015) and Gomes et al. (2019) reported that, due to anthropological activities on the banks, the Doce River was already polluted before the disaster. Despite this, Quadra et al. (2019) and Gomes et al (2019) reported increments of Fe, Mn, Al, Cu, and Pb in the Doce River 
shortly after the arrival of the mud from the collapse of the dam. Macêdo et al. (2020) found that the metals found in the highest concentrations in the Doce River's water 32 months after the disaster were Al and Fe. The results obtained in the water analysis of the present study (32-44 months after the disaster) corroborate with what was obtained by Macêdo et al. (2020), since the most abundant metals in the assessment carried out in this study were also Al and Fe. Even four years after the disaster, the results show that Al remains above the maximum limits allowed by Brazilian law (National Environmental Council, Resolution 357/2005) and by USEPA (1998). The results obtained in the analysis of the gonads corroborated, partially, the results obtained in the water analysis, with Al being the metals with the highest concentrations.

\section{4 .2. Biological Indices And Sexual Maturation}

According to Vicentini and Araújo (2003), the sex ratio between individuals is basic information for the reproductive potential, providing important data about the dynamics and population structure of a species. Súarez et al. (2017), studying A. lacustris in the Pantanal, Brazil, reported higher proportions of females and attributed this to differences in the proportion of birth, mortality and growth; in addition to the need for rapid population growth, as a compensatory response to predation. According to Vicentini and Araújo (2003), another factor that can influence the proportion between males and females is the availability of food. Súarez et al. (2017) also reported that the imbalance in the proportion of males and females is unfavorable for natural selection in the environment. Contrary to the findings by Súarez et al. (2017) with $A$. lacustris, the present study revealed a balanced proportion between males and females in the population of the lower Doce River, which is a beneficial factor for the reproduction of this population.

The onset of sexual maturity is an important component in the population dynamics of fish (Köster et al. 2013, Súarez et al. 2017). This study was not designed to estimate the age of the first sexual maturation of the population of $A$. lacustris from the lower Doce River; but, when analyzing the data obtained, we found an alarming result (Table 10). 
Table 10

Necessary proportional growth (CN in \%) for males and females of different species of the Astyanax genus, from $30-40 \%$ of mature individuals (L30 for males and L40 for females) to $50 \%$ of mature individuals (L50).

$\mathrm{TM}=$ maximum population size

\begin{tabular}{|c|c|c|c|c|c|c|c|c|c|c|}
\hline \multirow[t]{2}{*}{ Specie } & \multirow[t]{2}{*}{ Local } & \multicolumn{4}{|l|}{ Male } & \multicolumn{4}{|c|}{ Female } & \multirow[t]{2}{*}{ Reference } \\
\hline & & $\begin{array}{l}\text { TM } \\
(\mathrm{cm})\end{array}$ & $\begin{array}{l}\mathrm{L} 30 \\
(\mathrm{~cm})\end{array}$ & $\begin{array}{l}\mathrm{L} 50 \\
(\mathrm{~cm})\end{array}$ & $\begin{array}{l}\mathrm{CN} \\
(\%)\end{array}$ & $\begin{array}{l}\text { TM } \\
(\mathrm{cm})\end{array}$ & $\begin{array}{l}\mathrm{L} 40 \\
(\mathrm{~cm})\end{array}$ & $\begin{array}{l}\text { L50 } \\
(\mathrm{cm})\end{array}$ & $\begin{array}{l}\text { CN } \\
(\%)\end{array}$ & \\
\hline A. lacustris & $\begin{array}{l}\text { Doce } \\
\text { River, } \\
\text { Brazil }\end{array}$ & 17 & 5 & 11 & 35.29 & 18 & 7 & 11 & 22.22 & $\begin{array}{l}\text { Present } \\
\text { study }\end{array}$ \\
\hline A. lacustris & $\begin{array}{l}\text { Paraguai } \\
\text { River, } \\
\text { Brazil }\end{array}$ & 7 & 2.1 & 3.1 & 14.28 & 7 & 2.8 & 3.1 & 4.28 & $\begin{array}{l}\text { Súarez et } \\
\text { al. (2017) }\end{array}$ \\
\hline $\begin{array}{l}\text { A. } \\
\text { intermedius }\end{array}$ & $\begin{array}{l}\text { E. M. } \\
\text { Atlântica } \\
\text { Park, } \\
\text { Brazil }\end{array}$ & 9 & 3.6 & 3.9 & 3.33 & 9 & 4.3 & 4.4 & 1.11 & $\begin{array}{l}\text { Souza et } \\
\text { al. (2015) }\end{array}$ \\
\hline $\begin{array}{l}\text { A. } \\
\text { bifasciatus }\end{array}$ & $\begin{array}{l}\text { Iguaçu } \\
\text { River, } \\
\text { Brazil }\end{array}$ & 12 & 2.9 & 3.6 & 5.83 & 12 & 4 & 4.6 & 5 & $\begin{array}{l}\text { Oliveira et } \\
\text { al. (2019) }\end{array}$ \\
\hline A. henseli & $\begin{array}{l}\text { Dos } \\
\text { Sinos } \\
\text { River, } \\
\text { Brazil }\end{array}$ & 14 & 6.5 & 6.9 & 2.86 & 14 & 5.5 & 6 & 3.57 & $\begin{array}{l}\text { Dala- } \\
\text { Corte e } \\
\text { Azevedo } \\
(2010)\end{array}$ \\
\hline
\end{tabular}

Studying a smaller population of $A$. lacustris (maximum size $=7 \mathrm{~cm}$ for males and females), Súarez et al (2017) reported male individuals with $30 \%$ gonadal maturation at $2.1 \mathrm{~cm}$ in length and $50 \%$ at $3.1 \mathrm{~cm}$ in length. The difference between 30 and $50 \%$ of matured individuals was only $1 \mathrm{~cm}$ (growth $=14.28 \%$ ). On the other hand, the males in the present study needed to grow $6 \mathrm{~cm}$ (35.29\% of the maximum size), so that $30 \%$ of individuals with gonads passed to $50 \%$. Oliveira et al. (2019) reported that the population of $A$. bifasciatus in the lower Iguaçu River basin needed to grow $0.7 \mathrm{~cm}$ to pass from 30 to $50 \%$ of mature individuals, a growth of $5.83 \%$. Dala-Corte and Azevedo (2010) reported an even lower percentage of growth (2.86\%) in A. henseli, with a difference between 30 and $50 \%$ of individuals with gonads of only $0.4 \mathrm{~cm}$.

For females, the results are even more alarming (Table 10). Other studies with species of the genus Astyanax observed a much lower need for proportional growth $(1.11-5 \%)$ than that obtained in the present study, in order to increase from $40 \%$ of individuals with gonads to 50\% (Souza et al. 2015, Dala-Corte and Azevedo 2010, and Oliveira et al. 2019, respectively). For the population of $A$. lacustris in the Pantanal, it was necessary to increase $0.3 \mathrm{~cm}$ (4.28\% of the maximum size) to pass from $40 \%$ of individuals with gonads to $50 \%$ (Súarez et al., 2017 ). A. lacustris females from the lower Doce River needed to grow $22.22 \%$ to increase from $40 \%$ of individuals with gonads to $50 \%$. Only one female was collected with a length between 14 and $15 \mathrm{~cm}$, and it did not have evident gonads. This latency in the formation of gonads is a strong indication of a disruption in the reproductive biology of the population of $A$. lacustris from the lower Doce River and deserves to be the target of future investigations. Previous studies have reported that chronic exposure to metals, such as Al, can cause a delay in the sexual maturation of fish, as well as increased spermatogonia and spermatocytes and a significant decrease in 
spermatids and spermatozoa (Paschoalini et al., 2019). In fact, Chaube et al. (2010) demonstrated that metals are able to bind to androgen and progesterone receptors changing their functions.

Another factor observed is that $A$. lacustris individuals from the lower Doce River showed a size greater than $60 \%$ of the maximum size for $50 \%$ of the population to have gonads (male $=64 \%$ and female $=61 \%$ ). The population of $A$. lacustris of the Paraguay River has $50 \%$ of individuals with gonads with $44.28 \%$ of the maximum size, for both males and females.

The reproduction peak found in this study was in Sep Oct for females and Jan Feb for males during the rainy season in the region. Species of the Astyanax genus usually have a seasonal breeding strategy, increasing in the rainy season, between spring and summer (Dala-Corte and Azevedo 2010). Gurgel et al. (2004) and Araújo et al. (2019) reported the same reproductive peak in the summer, coinciding with rainy peaks in the region. These results corroborate the results obtained in the present study. Súarez et al. (2017) also found this increase in the periods from Nov Dec to Jan Feb, and reported that both the increase in rain and temperature create more favorable conditions for the development and feeding of juveniles (Oliveira et al. 2010). In addition, the high volume and high waterflow found at UHE Mascarenhas may influence the increase in reproduction during the rainy season as a strategy to maximize the fitness of $A$. lacustris.

Although the present study found a higher percentage of gonads with reproductive capacity in the rainy season, the other periods also showed matured gonads in a lower percentage, which indicates multiple reproduction. Souza et al. (2015) suggest that this fragmented reproduction strategy may be associated with the unpredictable nature of the region's conditions, a reality observed at UHE Mascarenhas due to the high volume of water released in the region. Súarez et al. (2017) raise the hypothesis that the hydrological unpredictability of the breeding regions of Astyanax species leads to the evolution of different reproductive strategies for the species of the genus. Some populations use total reproduction as a strategy to maximize fitness, such as the population of $A$. lacustris in the upper Paraná River basin. Other populations - such as A. bimaculatus, studied by Araújo et al. (2019) - presented results, similar to the present study, in a reservoir in Paraíba do Sul in southeastern Brazil. Araújo et al. (2019) justify this behavior as a way of reducing juvenile predation and competition for food and shelter. With multiple reproduction, different niches are occupied and this leads to less competition among adults for spawning sites and, among larvae, for food resources.

\subsection{Concentration of metals in the gonads}

Through a study done with Barbus grypus, Barbus sharpeyi and Cyprinus carpio, Alhashemi et al. (2012) concluded that sex is an important factor and that it can interfere with the bioaccumulation of metals in fish. In B. grypus and $B$. sharpeyi, a greater bioaccumulation of metals was observed in females when compared to males. However, in $C$. carpio, males showed greater bioaccumulation of metals when compared to females. This result corroborates with the ones observed in the present study since, in relation to $\mathrm{Al}, \mathrm{Cr}$, Fe and $\mathrm{Pb}$, males bioaccumulated significantly higher concentrations than females. The other metals showed no significant difference in relation to the sex of the individuals.

According to Passos et al. (2020), the lower Doce River is a region that has frequent resuspension events that can make elements, previously sedimented, available again in the water column. Silva et al. (2010) stated that the period from October to March had the highest rainfall. Thus, the metals considered the most abundant in the

Page $17 / 28$ 
lower Doce River region (Al and Fe) would become available and toxic during such resuspension events. Passos et al. (2020) reported high concentrations of Fe in the elutriate and sediment of the Doce River in November 2018 , with an average of $590 \mu \mathrm{g} . \mathrm{L}^{-1}$ and $26.04 \mathrm{mg} \cdot \mathrm{kg}^{-1}$, respectively. This corroborates the result found in the present study, which showed a higher concentration of Fe in the gonads of males in Sep Oct.

In freshwater fish, Al is known to affect their reproduction, as in the case of Oncorhhynchus mykiss (Hwang et al. 2000), due to a directly proportional reduction in vitellogenesis. In addition, acidified water, result of high concentrations of Al (Hwang et al. 2000 and Correia et al. 2010), is known to impair fish reproduction by affecting fertility, egg viability, spawning success, gonadal development, and production of gametes. These effects have serious consequences for fish populations exposed to Al (Correia et al. 2010). Passos et al. (2020) state that, in addition to Al, Fe also causes deleterious effects in fish exposed to the metal, which can lead to increased mortality and histopathological changes in liver cells. When compared to the results of the present study, it is concluded that, in addition to histopathologies in liver cells, Fe may also be responsible for histopathologies in gonadal cells.

Although Al and Fe showed higher concentrations in the gonads of the organisms, Cr presented a greater bioaccumulative effect in relation to other metals when BCF was calculated. Despite being an essential metal, $\mathrm{Cr}$ - in its hexavalent form, which normally corresponds to a fraction of the total Cr found in water (Campagna et al. 2013) - is considered mutagenic, carcinogenic and has several harmful impacts on biota (Bakshi and Panigrahi 2018). Bakshi and Panigrahi (2018) revealed that Cr can affect the behavioral, histological, biochemical, genetic, and immunological conditions of organisms; thus, it can be concluded that, although the concentration of $\mathrm{Cr}$ in the gonads was low, its potential for bioconcentration and contamination can lead to changes in the fish exposed to it.

\subsection{Histological damage to the gonads}

Among the histopathologies observed in the testicles of Clarias gariepinus exposed to xenobiotics, there is the release of immature cells into the lumen (Agbohessi et al. 2015). Da Cuña et al. (2013) also reported similar changes in Cichlasoma dimerus males exposed to an insecticide. The release of immature cells into the lumen is indicative of deficiency in spermatogenesis and, possibly, testicular functionality (Da Cuña et al 2011). Both the studies by Agbohessi et al. (2015) and Da Cuña et al. $(2011 ; 2013)$ corroborate the results obtained in this study, which observed the release of immature cells into the lumen in the testicles of $A$. lacustris in greater quantity (47.36\%) when compared to other histological damages found. The presence of testicular oocytes, found in a smaller quantity, is of great concern in the reproductive biology of $A$. lacustris. In dioecious fish, the presence of intersex is considered a signature of exposure to xenobiotics (Luzio et al. 2016). Although the genotype of intersex fish had not been determined, the macro and microscopic aspects of their gonads indicated that the individuals were male (Prado et al. 2011). Intersex gonads have been found in several studies carried out in rivers contaminated with xenobiotics in North America (Fossi et al. 2004), England (Hinck et al. 2009) and in the Mediterranean Sea (Jobling et al. 2009). Prado et al. (2011) conducted a study with Astyanax fasciatus in a reservoir in southeastern Brazil and, comparing the results obtained, this study found few individuals with the presence of gonads in intersex. Prado et al. (2011) reported a high prevalence of intersex in the studied organisms and suggested a high risk of contamination by xenobiotics at the collection sites. Although the prevalence in this study was lower, the presence of fish with intersex can directly impact the 
development and reproduction of offspring and, consequently, the population of $A$. lacustris in the lower Doce River can be affected in the long term (Prado et al. 2011).

According to Dyer (2007), metals can act as xenobiotics in exposed organisms through specific high-affinity pathways, such as, for example, the interaction with estrogen receptors. In a study by Luzio et al. (2016) with Danio rerio, the authors emphasize that exposure to xenobiotics can delay the development of oocytes, inducing them to death and potentially reducing the individual's reproductive success. Luzio et al. (2016) found a significant number of atretic oocytes and considered it the major responsible for the increase in the damage rate in the collected female gonads. Atresia is a degenerative and resorption process that occurs, both naturally and under conditions of environmental contamination (Weber et al. 2003). The results obtained by Luzio et al. (2016) corroborate the results found in the present study. Oocyte atresia was the most frequently damage found in the female organisms studied, with a prevalence of $39.64 \%$ in relation to the other histological damages analyzed. Studies with Pimephales promelas (Kidd et al. 2007) and Chalcalburnus tarichi (Kaptaner and Ünal 2011) also obtained similar results, with a high rate of atresia in organisms exposed to xenobiotics.

Cardoso et al. (2018) performed an experiment with Danio rerio females in order to confirm the applicability of the semi-quantitative method of counting in female gonads. Despite correctly establishing the stage of gonadal maturation, Cardoso et al $(2017,2018)$ concluded that, if the objective was to obtain a general classification of maturation or some differences between treatments, the semi-quantitative method is considered appropriate; however, if the objective of the work is to explore in detail the structural components of the gonads (such as primary, cortical, vitellogenic, and previtellogenic oocytes), the recommended method is the quantitative one. The present study confirms this statement since the stages of gonadal maturation of males and females were successfully determined by the semi-quantitative method. Nonetheless, when a more detailed analysis of female gonads was made using the quantitative method, the correlation between histological damage and the concentration $\mathrm{Al}$ and Fe was significantly positive. The qualitative method did not obtain any significant results in relation to metals. Moreover, when the results were classified into levels of histological damage, the semiquantitative method classified females classified as Class 2 of histological damage with moderate changes. On the other hand, the quantitative methodology classified females as Class 3 of histological damage with clear alterations in the tissue of the organ. Thus, it is concluded that the method of quantitative determination of histological damage in female gonads from A. lacustris is more recommended than the semi-quantitative method.

\section{Conclusions}

The environmental disaster caused by the rupture of the Fundão dam raised the concentration of metals in the water, such as $\mathrm{Al}$ and $\mathrm{Fe}$, of the affected region, a scenario that persists until today, as observed in the present study and previous ones. The population of $A$. lacustris from the lower Doce River shows obvious deleterious effects on the gonads as: 1) latency formation; 2) high concentrations of Al and Fe; and 3) clear histological alterations, such as the presence atresia, hyperplasia and the invasion of immature cells into the lumen. In females, there is a positive correlation between the concentration of $\mathrm{Al}$ in the gonads and the histological damage index estimated by the quantitative method. Our results allow us to predict that the permanence of high concentrations of metals (ex: $\mathrm{Cr}$, Fe and $\mathrm{Al}$ ) in the water of the lower Doce River will continue to subject the population of $A$. lacustris to harmful effects on the gonads. This long-term scenario may further compromise 
the reproductive success of this population and, consequently, of other species that are in a higher level in the trophic chain.

\section{Declarations}

\section{Ethics approval}

The project was carried out with the approval of the animal ethics committee (CEUA/UVV \# 563-2018).

\section{Consent to participate}

Not applicable.

\section{Consent to publish}

Not applicable.

\section{Availability of data and materials}

All data generated or analyzed during this study are included in this published article and its supplementary information files.

\section{Competing interests}

The authors declare that they have no competing interests.

\section{Funding}

Research and Innovation Fundation of Espírito Santo (FAPES) financialy supported (grant \#19/2017) and granted a scholarship to JM, DSC, BCT, and AB.

The Brazilian Coordination for the Qualification of Higher Level Personnel (CAPES) granted a scholarship to TMP (Finance code 001).

The Brazilian National Council for Scientific and Technological Development (CNPq) granted a scholarship to to LCG and SN

\section{Authors' contributions}

JM contributed to the study conceptualization, the formal analysis, the investigation, methodology, project administration, supervision, visualization and to both writings - original draft and review \& editing; The investigation and the Project administration were also performed by DSC and BCT; TMP, AB, CV and SN performed the investigation and LCG contributed with all roles, except for the investigation and the writing of original draft.

\section{References}


1. Agbohessi PT, Toko II, Ouedraogo A, Jauniaux T, Mantiki SNM, Kastemont P (2015) Assessment of the health status of wild fish inhabiting a cotton basin heavily impacted by pesticides in Benin (West Africa). Sci Total Environ 506-507, 567-584. https://doi.org/10.1016/j.scitotenv.2014.11.047

2. Agência Nacional de Águas (ANA) (2020) Sistema de Informações Hidrológicas. Disponível em: http://www.snirh.gov.br/hidroweb/serieshistoricas

3. Alhashemi AH, Karbassi A, Kiabi BH, Monavari SM, Sekhavatjou MS (2012) Bioaccumulation of trace elements in different tissues of three commonly available fish species regarding their gender, gonadosomatic index, and condition factor in a wetland ecosystem. Environ Monit Assess 184:1865-1878. https:// doi.org/10.1007/s10661-011-2085-8

4. Araújo FG, Nascimento AA, Gomes ID, Sales A, Oliveira BAC (2019) Gonadal development and reproductive period of the characin Astyanax aff. bimaculatus (Characiformes: Characidae) in a tropical reservoir in southeastern Brazil. Zool 36. https://doi.org/10.3897/zoologia.36.e30610

5. Bakshi A, Panigrahi AK (2018) A comprehensive review on chromium induced alterations in fresh water fishes. Toxicol Rep 5:440-447. https://doi.org/10.1016/j.toxrep.2018.03.007

6. Baroiller JF, Guiguen Y (2001) Endocrine and environmental aspects of sex differentiation in gonochoristic fish. In: Scherer G, Schmid M (Eds.) Genes and Mechanisms in Vertebrate Sex Determination. Experientia Suppl vol 91. Birkhäuser, Basel.

7. Bernardino AF, Pais FS, Oliveira LS, Gabriel FA, Ferreira TO, Queiroz HM, Mazzuco ACA (2019) Chronic trace metals effects of mine tailings on estuarine assemblages revealed by environmental DNA. PeerJ 7;7:e8042. https://doi.org/10.7717/peerj.8042.

8. Bernet D, Schmidt H, Meier W, Burkhardt-Holm P, Wahli T (1999) Histopathology in fish: proposal for a protocol to assess aquatic pollution. J Fish Dis 22(1):25-34. https://doi.org/10.1046/j.1365-

2761.1999.00134.x

9. Blain BJ, Sutton TM (2016) Reproductive Status and Blood Plasma Indicators of Sex and Gonad Maturation Status for Yelloweye Rockfish Following Barotrauma and Recompression Events. Trans Am Fish Soc 145(6):1234-1240. https://doi.org/10.1080/00028487.2016.1225598

10. Blazer VS (2002) Histopathological assessment of gonadal fish tissue in wild fishes. Fish Physiol Biochem 26:85-101. https://doi.org/10.1023/A:1023332216713

11. Braunbeck T, Storch V, Bresch H (1990) Species-specific reaction of liver ultrastructure in zebrafish (Brachydanio rerio) and trout (Salmo gairdneri) after prolonged exposure to 4-chloroaniline. Arch Environ Conta Toxicol 19:405-418. https://doi.org/10.1007/BF01054986

12. Campagna AF, Rodrigues BK, Nogueirol RC, Verani NF, Espíndola ELG, Alleoni LRF (2013) Use of artificial sediment to assess toxicity of chromium on Chironomus xanthus, Danio rerio and Poecilia reticulata. Acta Limnol Bras 25(1). https://doi.org/10.1590/S2179-975X2013000100006

13. Cantanhêde SM, Silva, CG, Pereira NJ, Pinho CJS, Silva J, Tchaicka L, Neta RN, Torres JRS, Santos DM (2016) Evaluation of environmental quality of two estuaries in Ilha do Maranhão, Brazil, using histological and genotoxic biomarkers in Centropomus undecimalis (Pisces, Centropomidae). Environ Sci Pollut Res 23(20):21058-21069. https://doi.org/10.1007/s11356-016-7294-9

14. Cardoso PG, Rodrigues D, Madureira TV, Oliveira N, Rocha MJ, Rocha E (2017) Warming modulates the effects of the endocrine disruptor progestin levonorgestrel on the zebrafish fitness, ovary maturation 
kinetics and reproduction success. Environ Pollut 229:300-311.

https://doi.org/10.1016/j.envpol.2017.05.090.

15. Cardoso PG, Rodrigues D, Madureira TV, Rocha MJ, Roch, E (2018) Histopathological Evaluation of Combined Impacts of the Synthetic Progestin Levonorgestrel and Temperature on the Female Zebrafish Maturation Using a Semi-quantitative Grading Analysis-Is it Enough? Bull Environ Contam Toxicol 101:417-422. https://doi.org/10.1007/s00128-018-2436-z

16. Chaube R, Mishra S, Singh RK (2010) In vitro effects of lead nitrate on steroid profiles in the postvitellogenic ovary of the catfish Heteropneustes fossilis. Toxicol Vitr 24:1899-1904. https://doi.org/10.1016/j.tiv.2010.07.021

17. CONAMA - Conselho Nacional do Meio Ambiente (2005) Resolução n 357. Diário Oficial da União de 17 de Março de 2005. http://www.mma.gov.br/port/conama/legiabre.cfm?codlegi=459 (accessed 25 Apr 2020).

18. Correia TG, Narcizo AM, Bianchini A, Moreira RG (2010) Aluminum as an endocrine disruptor in female Nile tilapia (Oreochromis niloticus). Comp Biochem Physiol C Toxicol Pharmacol 151(4):461-466. https://doi.org/10.1016/j.cbpc.2010.02.002

19. Couture P, Pyle G (2012) Field studies on metal accumulation and effects in fish. Fish Physiol Part $A$ 31:417-473. https://doi.org/10.1016/S1546-5098(11)31009-6

20. Da Cuña RH, Vázquez GR, Piol MN, Noemí VG, Maggese MC, Lo Nostro FL (2011) Assessment of the acute toxicity of the organochlorine pesticide endosulfan in Cichlasoma dimerus (Teleostei, Perciformes). Ecotoxicol Environ Saf 74(4):1065-1073. https://doi.org/10.1016/j.ecoenv.2011.02.002

21. Da Cuña RH, Pandolfi M, Genovese G, Piazza Y, Ansaldo M, Lo Nostro FL (2013) Endocrine disruptive potential of endosulfan on the reproductive axis of Cichlasoma dimerus (Perciformes, Cichlidae). Aquat Toxicol 126:299-305. https://doi.org/10.1016/j.aquatox.2012.09.015

22. Dala-Corte R, Azevedo MA (2010) Reproductive biology of Astyanax henseli (Teleostei, Characidae) in the upper reaches of the Sinos River, RS, Brasil. Iheringia, Sér Zool.100(3):259-266.

https://doi.org/10.1590/S0073-47212010000300012

23. Dos Santos JA, Soares CM, Bialetzki A (2020) Early ontogeny of yellowtail tetra fish Astyanax lacustris (Characiformes: Characidae). Aquac Res 00:1-13. https://doi.org/10.1111/are.14746

24. Duruibe JO, Ogwuegbu MOC, Egwurugwu JN (2007) Heavy metal pollution and human biotoxic effects. Int J Phys Sci 2(5):112-118. http://www.academicjournals.org/IJPS

25. Dyer (2007) Heavy Metals as Endocrine-Disrupting Chemicals. In: Gore AC (ed) Endocrine-Disrupting Chemicals: From Basic Research to Clinical Practice Humana. Press Inc, Totowa, NJ. 111-133. https://doi.org/10.1007/1-59745-107-X_5

26. Escobar H (2015) Mud tsunami wreaks ecological havoc in Brazil. Science 350(6265):1138-1139. https://doi.org/10.1126/science.350.6265.1138.

27. Fossi MC, Casini S, Marsili L, Ancora S, Mori G, Neri G, Romeo T, Ausili A (2004) Evaluation of ecotoxicological effects of endocrine disrupter during a four-year survey of the Mediterranean population of swordfish (Xiphias gladius). Mar Environ Res 58:425-429.

https://doi.org/10.1016/j.marenvres.2004.03.026

28. Godinho AL, Lamas IR, Godinho HP (2010) Reproductive ecology of Brazilian freshwater fishes. Environ Biol Fish 87:143-62. https://doi.org/10.1007/s10641-009-9574-4

Page 22/28 
29. Gomes LC, Chippari-Gomes AR, Miranda TO, Pereira TM, Merçon J, Davel VC, Barbosa BV, Pereira ACH, Frossard A, Ramos JPL (2019) Genotoxicity effects on Geophagus brasiliensis fish exposed to Doce River water after the environmental disaster in the city of Mariana, MG, Brazil. Braz J Biol 79(4). http://dx.doi.org/10.1590/1519-6984.188086.

30. Gomes LEO, Correa LB, Sá F, Neto RR, Bernardino AF (2017) The impacts of the Samarco mine tailing spill on the Rio Doce estuary, Eastern Brazil. Mar Pollut Bull 120:28-36. http://dx.doi.org/10.1016/j.marpolbul.2017.04.056

31. Greenfield BK, Teh SJ, Ross JRM, Hunt J, Zhang GH, Davis JA, Ichikawa G, Crane D, Hung SSO, Deng DF, Teh FC, Green PG (2008) Contaminant concentrations and histopathological effects in Sacramento splittail (Pogonichthys macrolepidotus). Arch Environ Contam Toxicol 55(2):270-281. https://doi.org/10.1007/s00244-007-9112-3

32. Gurgel HCB (2004) Populational structure and reproduction season of Astyanax fasciatus (Cuvier) (Characidae:Tetragonopterinae) in the Ceará Mirim River, Poço Branco, Rio Grande do Norte, Brazil. Rev Brasil Zool 21(1):131-135. https://doi.org/10.1590/S0101-81752004000100022

33. Hink JE, Blazer VS, Schmitt CJ, Papoulias DM, Tillitt DE (2009) Widespread occurrence of intersex in black basses (Micropterus spp.) from U.S. rivers, 1995-2004. Aquat Toxicol 95(1):60-70. https://doi.org/10.1016/j.aquatox.2009.08.001

34. Hinton DE, Lauren DJ (1990) Liver structural alterations accompanying chronic toxicity in fishes: potential biomarkers of exposure. In: McCarthy JF, Shugart LR (Eds.) Biomakers of Environmental Contamination. Lewis Publishers, Boca Raton, FL, 17-57.

35. Hwang U, Kagawa N, Mugiya Y (2000) Aluminium and Cadmium Inhibit Vitellogenin and Its mRNA Induction by Estradiol-17 b in the Primary Culture of Hepatocytes in the Rainbow Trout Oncorhynchus mykiss. Gen Comp Endocrinol 119:69-76. doi:10.1006/gcen.2000.7494

36. James MO (2011) Journal of Steroid Biochemistry and Molecular Biology Steroid catabolism in marine and freshwater fish. J Steroid Biochem Mol Biol 127:167-175. https://doi.org/10.1016/j.jsbmb.2010.10.003

37. Jeffery WR (2001) Cavefish as a model system in evolutionary developmental biology. Dev Biol 231:1-12. https://doi.org/10.1006/dbio.2000.0121

38. Jobling S, Burn RW, Thorpe K, Williams R, Tyler C (2009) Statistical modelling suggests that antiandrogens in effluents from wastewater treatment works contribute to widespread sexual disruption in fish living in English rivers. Environ Health Perspect 117:797-802. https://doi.org/10.1289/ehp.0800197

39. Kaptaner B, Ünal G (2011) Effects of 17-ethynylestradiol and nonylphenol on liver and gonadal apoptosis and histopathology in Chalcalburnus tarichi. Environ Toxicol 26:610-622.

https://doi.org/10.1002/tox.20585

40. Kidd KA, Blanchfield PJ, Mills KH, Palace VP, Evans RE, Lazorchak JM, Flick RW (2007) Collapse of a fish population after exposure to a synthetic estrogen. Proc Natl Acad Sci 104:8897-8901. https://doi.org/10.1073/pnas.0609568104

41. Kime DE (1998) Endocrine Disruption in Fish. Kluwer Academic Publishers, Norwell.

42. Köster FW, Trippel EA, Tomkiewicz J (2013) Linking size and age at sexual maturation to body growth, productivity and recruitment of Atlantic cod stocks spanning the North Atlantic. Fish Res 138:52-61. https://doi.org/10.1016/j.fishres.2012.07.002 
43. Liu X, Jiang J, Yan Y, Dai Y, Deng B, Ding S, Su S, Sun W, Li Z, Gan Z (2018) Distribution and risk assessment of metals in water, sediments, and wild fish from Jinjiang River in Chengdu, China.

Chemosphere 196:45-52. https://doi.org/10.1016/j.chemosphere.2017.12.135

44. Lucena CAS, Soares HG (2016) Review of species of the Astyanax bimaculatus "caudal peduncle spot" subgroup sensu Garutti \& Langeani (Characiformes, Characidae) from the rio La Plata and rio São Francisco drainages and coastal systems of southern Brazil and Uruguay. Zootaxa 4072(1):101-25. https://doi.org/10.11646/zootaxa.4072.1.5

45. Lütken CF (2001) Peixes do Rio das Velhas: Uma contribuição para a Ictiologia do Brasil. In: Alves CBM, Pompeu PS.(Org.) Peixes do Rio das Velhas: passado e presente. Belo Horizonte, SEGRAC. cap. 2, 23-164.

46. Luzio A, Monteiro SM, Rocha E, Fontaínhas-Fernandes AA, Coimbra AM (2016) Development and recovery of histopathological alterations in the gonads of zebrafish (Danio rerio) after single and combined exposure to endocrine disruptors (17-ethinylestradiol and fadrozole). Aquat Toxicol 175:90-105.

http://dx.doi.org/10.1016/j.aquatox.2016.03.014

47. Merciai R, Guasch H, Kumar A, Sabater S, Garcia-Berthou E (2015) Trace metal concentration and fish size: Variation among fish species in a Mediterranean river. Ecotoxicol Environ Saf 107:154-161. https://doi.org/10.1016/j.ecoenv.2014.05.006

48. Moretto EM (2001) Diversidade Zooplanctônicas e variáveis Limnológicas das Regiões Limnética e Litorânea de cinco Lagoas do Vale do Rio Doce. MG, e suas relações com o entorno. Escola de Engenharia de São Carlos, Universidade de São Paulo, Dissertação de Mestrado, 310p.

49. Nenciu M, Oros A, Roşioru D, Galaţchi M, Filimon A, Ţiganov G, Danilov C, Roşoiu N (2016) Heavy metal bioaccumulation in marine organisms from the Romanian Black Sea coast. Acad Romanian Sc. Ann Ser Biol Sci 5(1):38-52.

50. Neto R, Sá F, Schettini E, Dacol B (2016) Geoquímica de metais e nutrientes [online]. Disponível em: http://www.icmbio.gov.br/portal/images/stories/DCOM_geoquimica_soloncy_ufes.pdf.

51. OECD (2010) Guidance Document on the Diagnosis of Endocrine-related Histopathology in Fish Gonads. OECD Series on Testing and Assessment No. 123. Organization for Economic Cooperation and Development, Paris, France.

52. Omar WA, Zaghloul KH, Abdel-Khalek AA, Abo-Hegab S (2012) Genotoxic effects of metal pollution in two fish species, Oreochromis niloticus and Mugil cephalus, from highly degraded aquatic habitats. Mutat Res 746(1):7-14. http://dx.doi.org/10.1016/j.mrgentox.2012.01.013.

53. Oliveira CLC, Fialho CB, Malabarba LR (2010) Reproductive period, fecundity and histology of gonads of two cheirodontines (Ostariophysi: Characidae) with different reproductive strategies - insemination and external fertilization. Neotrop Ichthyol 8(2):351-360. http://dx.doi.org/10.1590/S1679-62252010000200014

54. Oliveira EC, Auache-Filho AA, Damasio D, Ghisi NC, Michels-Souza MA (2019) Reproductive indicators of the endemic species Astyanax bifasciatus (Teleostei: Characidae) in a tributary of the Lower Iguaçu River Basin, Brazil. Acta Sci Biol Sci 41. https://doi.org/10.4025/actascibiolsci.v41i1.47720

55. Paschoalini AL, Savassi LA, Arantes FP, Rizzo E, Bazzoli N (2019) Heavy metals accumulation and endocrine disruption in Prochilodus argenteus from a polluted neotropical river. Ecotoxicol Environ Saf 169:539-550. https://doi.org/10.1016/j.ecoenv.2018.11.047 
56. Passos LS, Gnocchi KG, Pereira TM, Coppo GC, Cabral DS, Gomes LC (2020) Is the Doce River elutriate or its water toxic to Astyanax lacustris (Teleostei: Characidae) three years after the Samarco mining dam collapse? Sci Total Environ 736. https://doi.org/10.1016/j.scitotenv.2020.139644

57. Prado PS, Souza CC, Bazzoli N, Rizzo E (2011) Reproductive disruption in lambari Astyanax fasciatus from a Southeastern Brazilian reservoir. Ecotoxicol Environ Saf 74:1879-1877. https://doi.org/10.1016/j.ecoenv.2011.07.017

58. Regulation (EC) No 1907/2006 of the European Parliment and of the Concil of 18 December 2006 concerning the Registration, Evaluation, Authorisation and Restriction of Chemicals (REACH), establishing a European Chemicals Agency, amending Directive 1999/45/EC and repealing Council Regulation (EEC) No 793/93 and Commission Regulation (EC) No 1488/94 as well as Council Directive 76/769/EEC and Commission Directives 91/155/EEC, 93/67/EEC, 93/105/EC and 2000/21/ EC. OJ L 396 2006, 1-849.

59. Sales RA, Oliveira EC, Delgado RC, Leite MCT, Ribeiro WR, Berilli SS (2018) Sazonal and interanual rainfall variability for Colatina, Espirito Santo, Brazil. Rev Sci Agrar 19(2):186-196.

60. Silva CF, Porto-Foresti F (2020) Pequenas centrais hidrelétricas no rio sapucaí-mirim (SP): diversidade e estrutura genética de Astyanax lacustris. Departamento de Ciências Biológicas, Universidade Estadual de São Paulo (UNESP), Dissertação de Mestrado.

61. Silva JPA, Muelbert AE, Oliveira EC, Fávaro LF (2010) Reproductive tactics used by the Lambari Astyanax aff. fasciatus in three water supply reservoirs in the same geographic region of the upper Iguaçu River. Neotrop Ichthyol 8(4):885-892. http://dx.doi.org/10.1590/S1679-62252010000400019

62. Souza UP, Ferreira FC, Carmo MAF, Braga FMS (2015) Feeding and reproductive patterns of Astyanax intermedius in a headwater stream of Atlantic Rainforest. Na Acad Bras Ciênc 87(4):2151-2162. http://dx.doi.org/10.1590/0001-3765201520140673

63. Súarez YR, Silva EA, Viana LF (2017) Reproductive biology of Astyanax lacustris (Characiformes: Characidae) in the southern Pantanal floodplain, upper Paraguay River basin, Brazil. Environ Biol Fish 100:775-783. https://doi.org/10.1007/s10641-017-0604-3

64. Tolussi CE, Gomes ADO, Kumar A, Ribeiro CS, Lo Nostro FL, Bain PA, de Souza GB, Da Cuña R, Honki RM, Moreira RG (2018) Environmental pollution affects molecular and biochemical responses during gonadal maturation of Astyanax fasciatus (Teleostei: Characiformes: Characidae). Ecotoxcol Environ Saf 147:926934. https://doi.org/10.1016/j.ecoenv.2017.09.056

65. USEPA (1976) Toxic Substances Control Act (TSCA). Available online at http://www.epa.gov/agriculture/tsca.html.

66. USEPA (1998) EPA Method 823-B-98-004: Evaluation of Dredged Material Proposed for Discharge in Waters of the U.S. Testing Manual, Inland Testing Manual.

67. Van der Oost R, Beyer J, Vermeulen NPE (2003) Fish bioaccumulation and biomarkers in environmental risk assessment: a review. Environ Toxicol Pharmacol 13:57-149. https://doi.org/10.1016/S13826689(02)00126-6

68. Van Dyk JC, Marchand MJ, Smit NJ, Pieterse GM (2009) A histology-based fish health assessment of four commercially and ecologically important species from the Okavango Delta panhandle, Botswana. Afr J Aquat Sci 34(3):273-282. https://doi.org/10.2989/AJAS.2009.34.3.9.985 
69. Venturoti GP, Boldrini-França J, Kiffer WP, Francisco AP, Gomes AS, Gomes LC (2019a). Toxic effects of ornamental stone processing waste effluents on Geophagus brasiliensis (Teleostei: Cichlidae). Environ Toxicol Pharmacol 72. https://doi.org/10.1016/j.etap.2019.103268

70. Venturoti GP, Boldrini-França J, Gomes AS, Chisté B, Gomes LC (2019b) Geophagus brasiliensis (Teleostei: Cichlidae) as an indicator of toxicity of ornamental stone processing wastes. Comp Biochem Physiol C Toxicol Pharmacol 226. https://doi.org/10.1016/j.cbpc.2019.108639

71. Vested A, Giwercman A, Bonde JP, Toft G (2014) Persistent organic pollutants and male reproductive health. Asian J Androl 14(1):71-80. https://doi.org/10.4103/1008-682X.122345

72. Vetillard A, Bailhache T (2006) Effects of 4-n-Nonylphenol and Tamoxifen on Salmon GonadotropinReleasing Hormone, Estrogen Receptor, and Vitellogenin Gene Expression in Juvenile Rainbow Trout. Toxicol Sci 92(2):537-544. https://doi.org/10.1093/toxsci/kfl015

73. Viana LF, Súarez YR, Cardoso CAL, Crispim BA, Cavalcante DNC, Grisolia AB, Lima-Junior SE (2018) The Response of Neotropical Fish Species (Brazil) on the Water Pollution: Metal Bioaccumulation and Genotoxicit. Arch Environ Contam Toxicol 75:476-485. https://doi.org/10.1007/s00244-018-0551-9

74. Viana LF, Tondato KK, Súarez YR, Lima-Junior SE (2014) Influence of environmental integrity on the reproductive biology of Astyanax altiparanae (Garutti \& Britski, 2000) in the Ivinhema river basin. Acta Sci Biol Sci 36(2):165-173. https://doi.org/10.4025/actascibiolsci.v36i2.21052

75. Vicentini RN, Araújo FG (2003) Sex ratio and size structure of Micropogonias furnieri (Desmarest, 1823) (Perciformes, Sciaenidae) in Sepetiba Bay, Rio de Janeiro, Brazil. Braz J Biol 63(4):559-566. https://doi.org/10.1590/S1519-69842003000400003

76. Weber LP, Hill RL, Janz DM (2003) Developmental estrogenic exposure in zebrafish (Danio rerio): II. Histological evaluation of gametogenesis and organ toxicity. Aquat Toxicol 63:431-446. https://doi.org/10.1016/S0166-445X(02)00208-4

77. Weber AA, Arantes FB, Sato Y, Rizzo E, Bazzoli N (2012) Oocyte adhesiveness and embryonic development of Astyanax bimaculatus (Linnaeus, 1758) (Pisces: Characidae). Zygote 21:198-202. https://doi.org/10.1017/S096719941200007X

78. Wester PW, Canton JH (1992) Histopathological effects in Poecilia reticulate (guppy) exposed to methyl mercury chloride. Toxicol Pathol 20:81-92. https://doi.org/10.1177/019262339202000110

79. Yancheva V, Velcheva I, Stoyanova S, Georgieva E (2016) Histological biomarkers in fish as a tool in ecological risk assessment and monitoring programs: A review. Appl Ecol Environ Res 14(1):47-75. https://doi.org/10.15666/aeer/1401_047075

80. Yevich PP, Yevich CA (1994) Use of histopathology in biomonitoring marine invertebrates. In: Kramer KJM (Ed). Biomonitoring of coastal waters and estuaries. CRC/Lewis Publishers, Boca Raton, Florida, 179-204.

81. Zeng J, Yang L, Wang X, Wang W, Wu QL (2012) Metal accumulation in fish from different zones of a large, shallow freshwater lake. Ecotoxicol Environ Saf 86:116-124. https://doi.org/10.1016/j.ecoenv.2012.09.003

\section{Figures}


Fig 1

a)

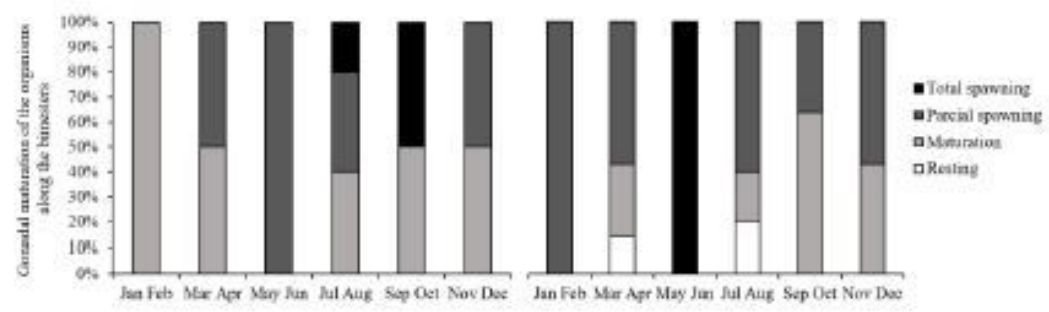

b)

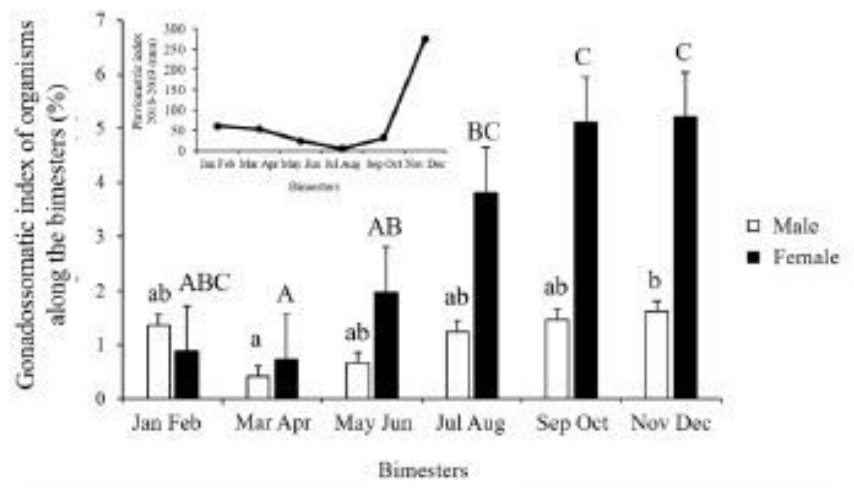

c)

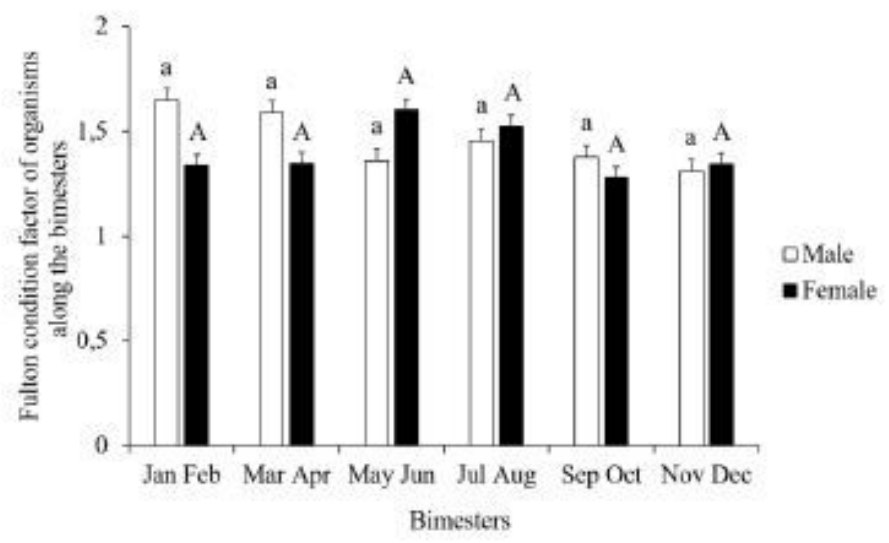

Figure 1

Annual distribution of a) relative frequency of different stages of ovarian and testicular maturation; $b$ ) gonadosomatic index and c) Fulton condition factor of A. lacustris exposed to the Doce River mining tailings. Lower-case letters indicate a significant difference between bimonths in relation to males and upper-case letters indicate a significant difference between bimonths and females. Values are represented in mean and standard error 
Fig 2
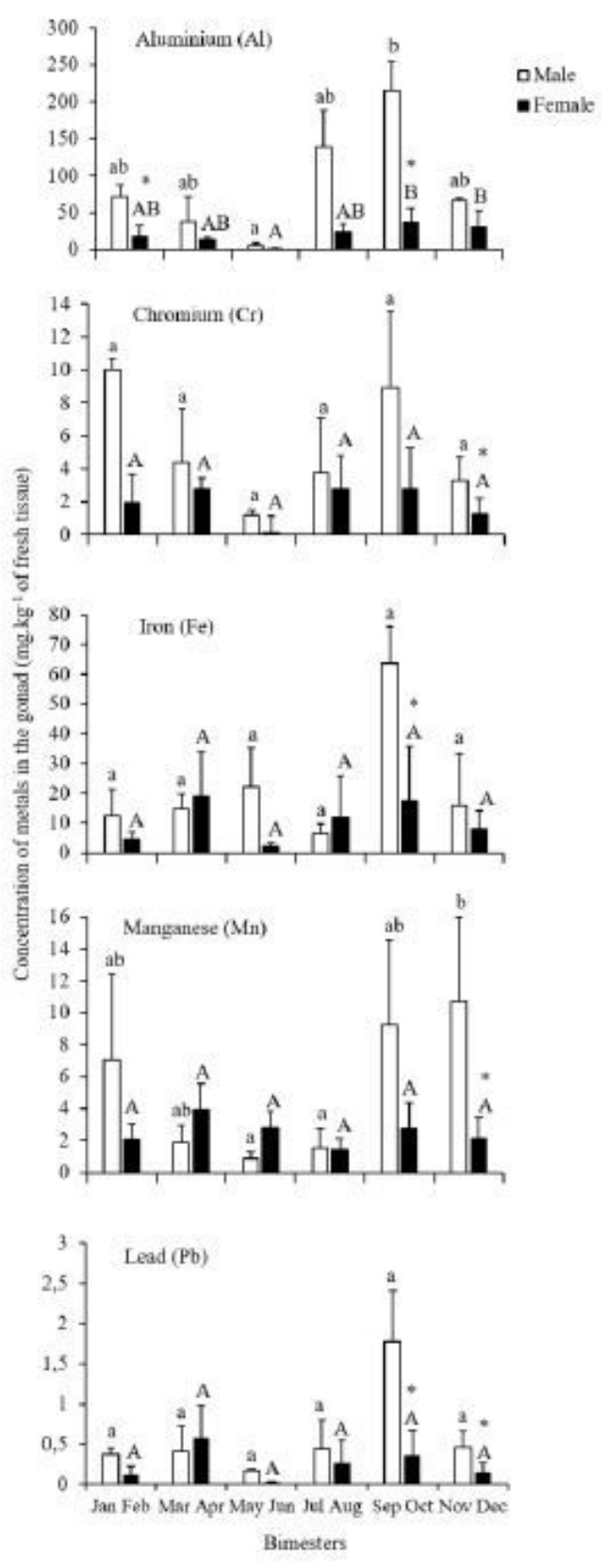

\section{Figure 2}

Concentration of metals in the gonads of individuals from A. lacustris exposed to mining waste from the Doce River. Values are represented in mean and standard error. Capital letters represent a significant difference in the bioaccumulation of metals, in males, in relation to periods. The lower-case letters represent a significant difference in the bioaccumulation of metals, in females, in relation to the periods. Asterisks ${ }^{*}$ ) represent a significant difference in the bioaccumulation of metals between males and females 